\title{
Saving Ghana from Its Oil: The Case for Direct Cash Distribution
}

\section{Todd Moss and Lauren Young}

\begin{abstract}
Ghana can be considered a relative success story in Africa. We cite six variables—peace and stability, democracy and governance, control of corruption, macroeconomic management, poverty reduction, and signs of an emerging social contract - to suggest the country's admirable political and economic progress. The expected arrival of sizeable oil revenues beginning in 2011-13, however, threatens to undermine that progress. In fact, numerous studies have linked natural resources to negative outcomes such as conflict, authoritarianism, high corruption, economic instability, increased poverty, and the destruction of the social contract. The oil curse thus threatens the very outcomes that we consider signs of Ghana's success. This paper draws lessons from the experiences of Norway, Botswana, Alaska, Chad, and Nigeria to consider Ghana's policy options. One common characteristic of the successful models appears to be their ability to encourage an influential constituency with an interest in responsible resource management and the means to hold government accountable. The Alaska model in particular, which was designed explicitly to manufacture citizen oversight and contain oil-induced patronage, seems relevant to Ghana’s current predicament. We propose a modified version of Alaska's dividend program. Direct cash distribution of oil revenues to citizens is a potentially powerful approach to protect and accelerate Ghana's political and economic gains, and a way to strengthen the country's social contract. We show why Ghana is an ideal country to take advantage of this option, and why the timing is fortuitous. We conclude by confronting some of the common objections to this approach and suggest that new technology such as biometric ID cards or private mobile phone networks could be utilized to implement the scheme.
\end{abstract}

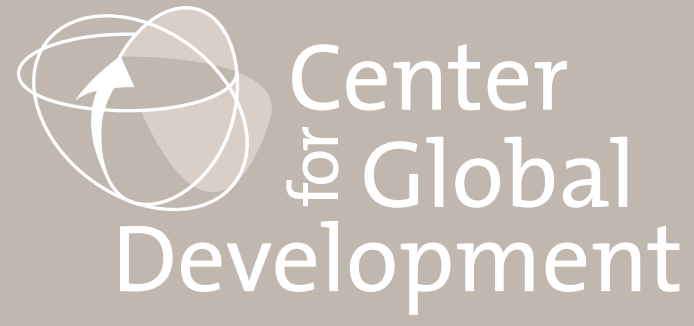

\section{Working Paper 186 October 2009}




\title{
Saving Ghana from Its Oil: The Case for Direct Cash Distribution
}

\author{
Todd Moss \\ Lauren Young \\ Center for Global Development
}

Todd Moss is vice president and senior fellow and Lauren Young is a research assistant at the Center for Global Development (www.cgdev.org) in Washington, D.C. We thank the Australian Agency for International Development for providing support that enabled this paper to be produced. For our title and many of the ideas in this paper, we are indebted to Nancy Birdsall and Arvind Subramanian and their article "Saving Iraq from Its Oil," Foreign Affairs, 2004. We also thank Kaysie Brown for her very useful background paper on natural resources and Jenny Aker for her insights on mobile phone networks. We thank Arvind Subramanian, Nancy Birdsall, Steve Radelet, Alan Gelb, Benjamin Leo, Ted Moran, Ian Gary, Antoine Heuty and several anonymous reviewers for comments on this draft, as well as enthusiastic input from our CGD colleagues during an internal research seminar. All errors in fact or judgment are solely those of the authors.

This paper was made possible by financial support from the Australian Agency for International Development.

Todd Moss and Lauren Young. 2009. "Saving Ghana from Its Oil: The Case for Direct Cash Distribution.” CGD Working Paper 186. Washington, D.C.: Center for Global Development.

http://www.cgdev.org/content/publications/detail/1422981

Center for Global Development 1800 Massachusetts Ave., NW Washington, DC 20036

202.416 .4000

(f) 202.416 .4050

www.cgdev.org
The Center for Global Development is an independent, nonprofit policy research organization dedicated to reducing global poverty and inequality and to making globalization work for the poor. Use and dissemination of this Working Paper is encouraged; however, reproduced copies may not be used for commercial purposes. Further usage is permitted under the terms of the Creative Commons License.

The views expressed in this paper are those of the author and should not be attributed to the board of directors or funders of the Center for Global Development. 
"The oil discovery is a good thing for Ghana. We can make it a 'blessing instead of a curse'."

- Ghana National Petroleum Corporation, January 16, 2008

\section{Introduction}

The first half of 2007 was a momentous time for Ghana. In March it celebrated its $50^{\text {th }}$ anniversary of independence. The outpourings of congratulations from world leaders stressed a similar theme: Ghana had led the way on independence, and now could lead the way on development. The country had achieved significant economic and political successes, and was in many ways a model that other African countries could emulate. Commonly-cited evidence was its growing democracy, including then four (now five) successive peaceful elections, and the economy's relatively high growth rates. Although the congratulatory rhetoric ignored major challenges that the country still faces, the cause for celebration was not unjustified.

Several months later another event sparked a second round of emotional outpouring, but the jubilation this time was tinged with trepidation. In June 2007 a consortium of foreign oil companies announced a "significant light oil accumulation" at an exploration well in the West Cape Three Points license offshore West Africa. Ghana had found oil.

The economic implications were immediately obvious. Early projections suggested that Ghana could soon be reaping more than a billion dollars per year from this one discovery. Gold mining and cocoa, the major sectors of the economy for more than a century, would almost immediately be surpassed by crude. Not unlike a lottery winner who has to decide whether to keep a day job or go shopping, Ghana seemed to suddenly have a whole new set of economic choices. The political fallout was less obvious. Using the oil revenues wisely was a major theme of the 2008 presidential campaign, but there was also growing concern that oil could have harmful effects on the polity. While Ghana's political classes have often felt in the shadow of Nigeria, there was also a strong sense of not wanting to repeat the mistakes of its giant oilexporting neighbor.

The new government of President John Atta Mills now faces a set of demanding policy choices that will determine the future of the country. Ghana has about two years until the oil revenues begin to flow. Getting the framework right early is essential; once entrenched interests set in, changing the system becomes extremely difficult. The government is currently receiving a flood of advice on how to manage its new source of wealth, and especially how to avoid the so-called "oil curse." There are many good suggestions on the table that will enhance transparency, improve citizen oversight, and hopefully allow Ghana's oil to benefit more than just a small elite.

This paper offers one option to complement this good advice, and one that can help lock in the benefits of transparency and accountability. We begin in Section Two by outlining six ways in which Ghana can be considered a success. Section Three looks at the literature on the natural resource curse and its impact on these very same six variables. Section Four draws out lessons 
from the experiences of Norway, Botswana, Alaska, Chad, and Nigeria, finding that one common characteristic of the successful models appears to be their ability to encourage an influential constituency with an interest in responsible resource management and the means to hold government accountable. In Section Five we propose direct cash distribution of oil revenues to citizens as the best approach to protect and accelerate Ghana's political and economic gains, and as a way to strengthen the country's social contract. We suggest why Ghana is an ideal country to take advantage of this option, and why the timing is in fact fortuitous. We conclude this section by confronting some of the common objections to this approach and suggest possible ways to implement the scheme.

\section{Measures of Ghana's success}

There is a multitude of ways to measure a country's performance. By most of the common political and economic measures, Ghana has been highly successful, especially relative to other developing countries or its own West African neighbors. We consider here six hopefully uncontroversial indicators of Ghana's relative progress.

2.1 Peace and stability. Ghana has been at peace since independence, with neither a civil war nor any violent conflict with foreign powers. It has had occasional outbreaks of localized violence in the northern regions, but these have always been contained. Ghana did experience a period of political instability, but since 1981 the country has been highly stable politically, returning to multiparty democracy in 1992 , holding five successive and mostly peaceful democratic elections (1992, 1996, 2000, 2004, 2008), and twice transitioning the executive office between opposing parties (NDC to NPP in December 2000, and the reversal in December 2008). The World Bank Institute governance indicator for "political stability and lack of violence" shows Ghana on a steadily upward trend and well above the regional average (Figure 1).

2.2 Democracy and governance. Ghana has been a multiparty democracy since 1992 and its citizens enjoy a high level of freedom in the media, speech, and political associations. All five of its elections have been, if far from perfect, of very high credibility and are widely believed to reflect the public will (Carter Center 1992; Jeffries and Thomas 1993; Jeffries 1998; 2005; Carter Center 2008). Ghana was one of only twenty countries (and the only country in Africa) identified by Carothers as "en route to becoming successful, well-functioning democracies" (2002). Ghana has steadily improved since the data began in 1996 in terms of World Bank governance indicators in "voice and accountability" and "rule of law" (Figure 2). Perhaps more importantly to Ghana's democracy, there is evidence that Ghanaians themselves are satisfied with the quality of democracy in their country. The Afrobarometer surveys find that Ghanaians are much more satisfied with the quality of democracy in their country than the average African 
and that satisfaction has risen between 2000 and 2005 by 16 percentage points, even as the region as a whole has seen a decline (Bratton and Cho 2006). ${ }^{1}$

2.3 Corruption. Ghana has taken visible steps to control corruption over the past two decades, and its efforts have been noticed both by independent measurements such as the World Bank governance indicators and by surveys of average Ghanaians. Corruption has also been a highprofile political issue for much of Ghana's independence period. Jerry John Rawlings justified his two coups in 1979 and 1981 largely on the basis of stamping out corruption. President John Kufuor's term was marked by greater press freedom, increased transparency, and the creation of a new Ghana Anti-Corruption Commission (Asamoa 2003; Gyimah-Boadi 2004). ${ }^{2}$ The World Bank indicator for the control of corruption, for example, shows that Ghana has significantly risen in terms of its ability to control corruption relative to the rest of the world from the $34^{\text {th }}$ percentile in 1996 to the $56^{\text {th }}$ percentile in 2008 (see Figure 3). Survey data shows that Ghanaians are becoming increasingly optimistic, and are far more optimistic than the rest of Africa (or in some polls, more optimistic than the rest of the world), about efforts to control corruption (Bratton and Cho 2006; Transparency International 2007). ${ }^{3}$

2.4 Macroeconomy. Ghana's track record on macroeconomic management has also been relatively strong. Since launching economic reforms in 1983, Ghana has liberalized economic controls and generally put in place measures to encourage higher economic growth, attract investment, and promote diversification (Aryeetey, Harrigan, and Nissanke 2000; Aryeetey and McKay 2007). Ghana has enjoyed a sustained average growth rate of $5.1 \%$ per year, or $2.8 \%$ per capita per year, over the last decade (both are almost a point higher than the Africa average) (World Bank 2009), which "represents one of the few growth success stories in subSaharan Africa" (Aryeetey and McKay 2007). At the same time, the inflation rate has been reduced and has more or less stabilized below 15\% since 2004 (Figure 4). Ghana has been fairly aggressive in privatization, removed most price controls, and lowered barriers to doing business. In the World Bank's Doing Business rankings, Ghana has pushed far ahead of its West African neighbors and is now ranked fourth among all low income countries (International Finance Corporation 2009). Inward flows of foreign direct investment have grown, with 2007 levels more than 30 times the flows of the early 1990s (UNCTAD 2009). Despite promising growth in some non-traditional sectors, the country remains highly dependent on just three traditional commodities (gold, cocoa, and timber) for more than $3 / 4$ of its exports (United Nations Statistics Division 2009).

\footnotetext{
${ }^{1}$ The surveys were conducted in 2000, 2002, and 2005 in Botswana, Ghana, Lesotho, Malawi, Mali, Namibia, Nigeria, South Africa, Tanzania, Uganda, Zambia, and Zimbabwe.

2 Since 2000, the media has been given greater freedom through the repeal of the criminal libel law and greater access to government data. Legislation has been passed that increases the transparency of the public procurement process, budget, and budgeting process, and provides protection to whistleblowers. The government has begun to enforce new laws by stopping criminal proceedings against journalists and sentencing a sitting minister.

${ }^{3}$ The Afrobarometer surveys show that the percentage of Ghanaians who believe that most or all national government officials are involved in corruption fell from 85\% in 2000 to level off around $25 \%$ in 2002 and 2005. Transparency International found that more than three in five Ghanaians in 2007 expected that corruption would decrease over the next three years, significantly more than the global average of only one in five, and seven in ten were positive about the effectiveness of efforts to fight corruption, compared to three in ten worldwide.
} 


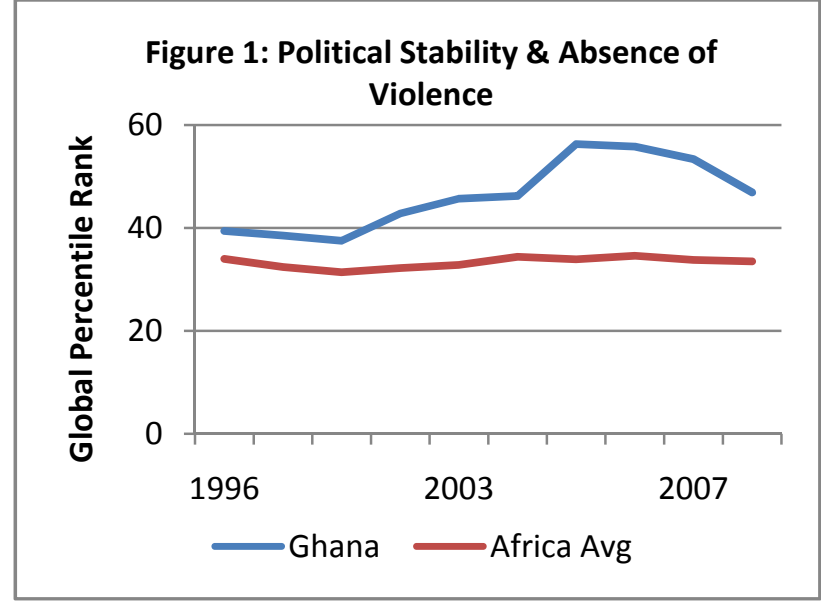

(Kaufmann, Kraay, and Massimo 2009)

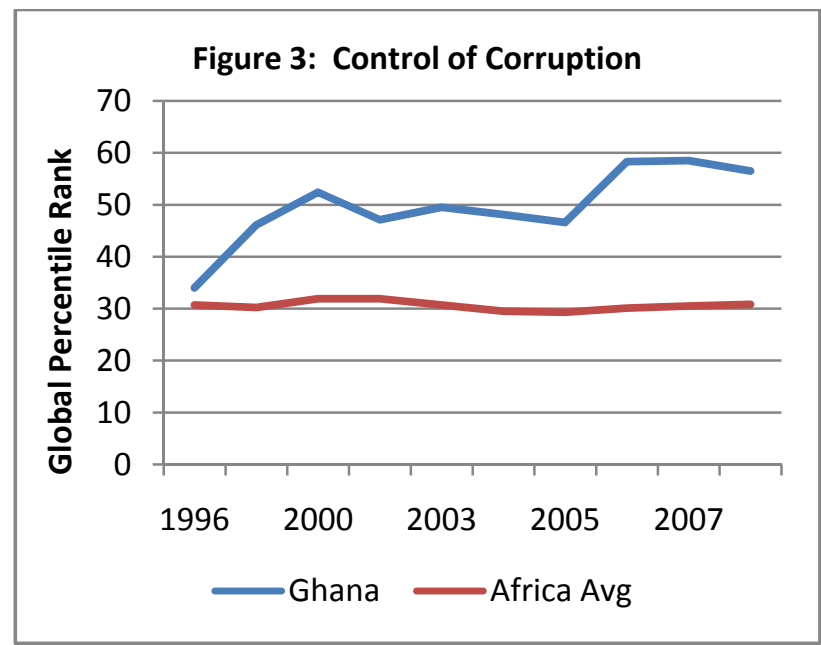

(Kaufmann, Kraay, and Massimo 2009)

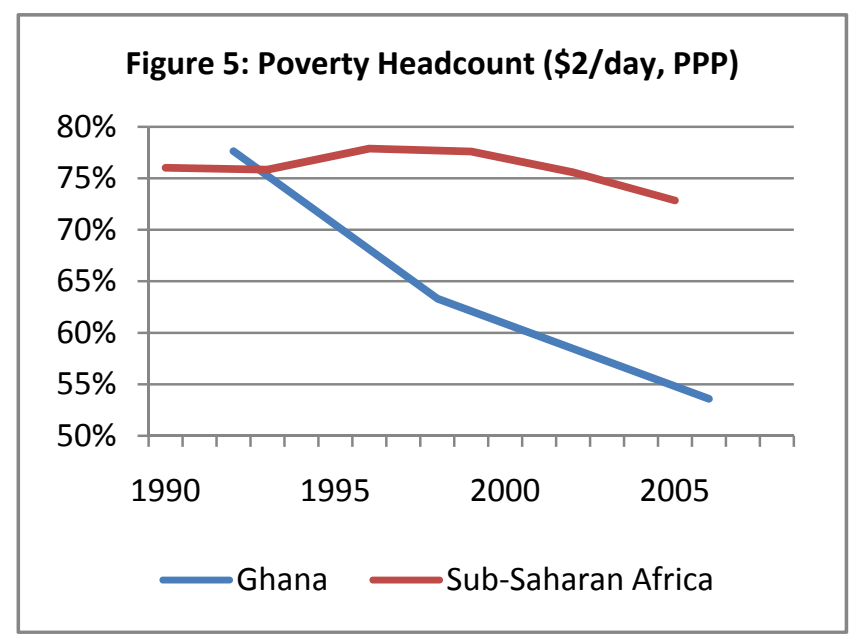

Source: (World Bank 2009)

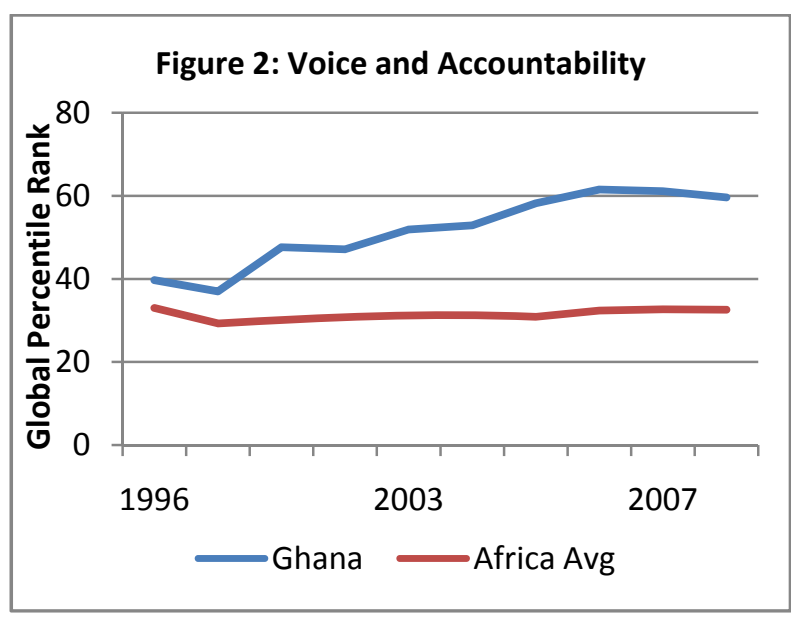

(Kaufmann, Kraay, and Massimo 2009)

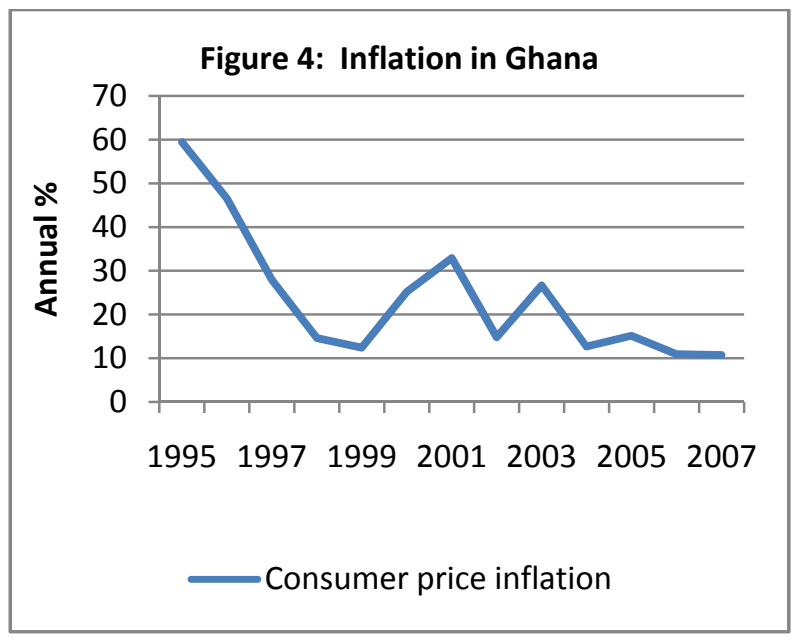

(World Bank 2009)

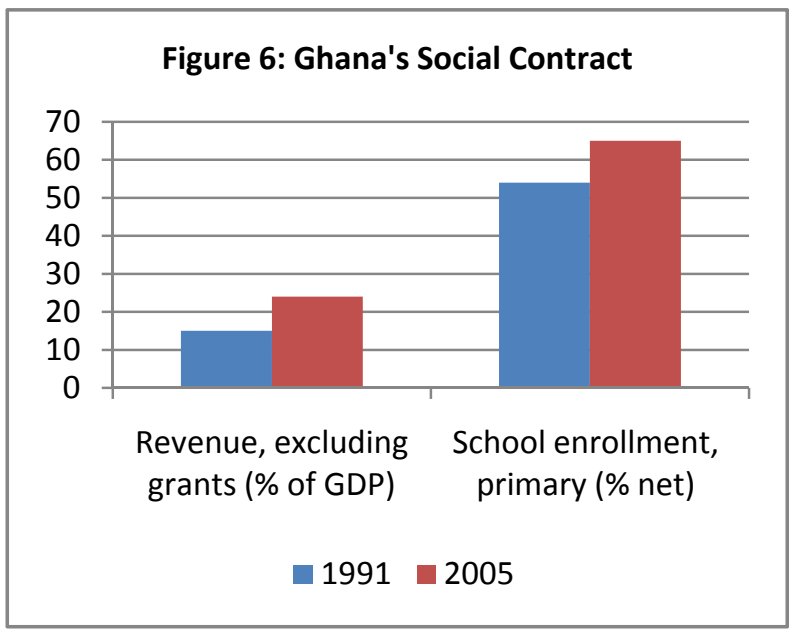

Source: (World Bank 2009) 
2.5 Poverty reduction. Sustained economic growth beginning in the 1980 s led to significant poverty reduction in the 1990s (Aryeetey and McKay 2007). The percentage of the population in Ghana below the \$2-per-day (PPP) poverty line fell from almost $80 \%$ in late 1980 s to $54 \%$ in 2006, an impressive feat considering that poverty in Sub-Saharan Africa as a whole barely fell at all over the same period (Figure 5). As a result of this strong performance, the UN recognizes Ghana as one of the very few African countries predicted to halve its 1990 poverty rate by 2015 (UNDP 2007).

2.6 Social contract. One of the foundations of democracy is a social contract between citizens and their government. The most basic element of this contract is that citizens give up rights and pay taxes in order to receive the benefits of social order and public services (Moore 1966). Ghana's recent economic and political success outlined above could be signs of just such a social contract. Over the past twenty years, the capacity of the government to collect taxes and provide social services has dramatically improved. To pick just two indicators: Ghana's government revenue has doubled from just 12\% of GDP in 1990 to 24\% in 2005 (and more than one-third of which is taxes on goods and services) while, during the same period, net primary school enrollment rose from $54 \%$ to $65 \%$ (Figure 6).

In sum, by six widely-used political and economic indicators of country performance, Ghana appears to be making impressive progress. Unfortunately, natural resources, and oil in particular, have been closely associated with deterioration in many of those very same outcomes.

\section{Harmful Effects of the Resource Curse}

The tendency of resource-rich countries to experience a host of poisonous outcomes is documented in an enormous body of literature on the so-called "natural resource curse" (Gelb 1988; Sachs and Warner 1995; Collier and Hoeffler 2000, to take only the most prominent sampling). Much of the research has converged on the negative impact of resource rents on institutions as the likely causal mechanism.

3.1 Conflict. There appears to be a robust correlation between natural resources and the likelihood and duration of civil wars. Many studies have used large cross-country samples to demonstrate that natural resource dependence is a better predictor of the outbreak of civil war than a number of other variables, including polarization and social fractionalization. In the seminal Collier and Hoeffler model, when primary commodity exports make up $33 \%$ of a country's GDP, the likelihood of conflict increases to $22 \%$ compared to $1 \%$ for a country with no such exports (2000). The literature is divided on the channels that might explain this connection, but the correlation remains largely undisputed. ${ }^{4}$

\footnotetext{
${ }^{4}$ The large body of literature written in response to Collier and Hoeffler's provocative model divides roughly into the "greed" and "grievance" camps. From the original "greed" argument that rebels take advantage of
} 
3.2 Authoritarianism. Other research has found a link between authoritarianism or poor democratic governance and natural resources. All of the 23 countries most dependent on oil and gas were under authoritarian rule at some point between 1974 and 2008 (Diamond 2008). Several of the earliest resource curse scholars developed the idea that "rentier states" are fiscally dependent on petrodollars or other resource rents. Rentier states have little need for taxation, which reduces or eliminates their accountability to their citizens and enables systems of patronage in which public spending is substituted for statecraft. Through rent seeking, public officials and their networks expand the reach of the state while undermining its authority and capacity (Karl 1997). Rents may also hinder democracy through two other channels: the "repression effect" by which resource wealth enables high military spending that quashes potential democratic pressures and the "modernization effect" where resource extraction industries stifle the emergence of a pro-democracy constituency of middle class citizens who typically emerge from manufacturing or the service sector (Ross 2001).

3.3 Corruption. Many of the resource curse theories use corruption as a key link in their causal chains; others treat corruption as a negative outcome in its own right. The theory linking resources and high levels of corruption is fairly simple: in the presence of high-rent, capitalintensive activities, there are more opportunities for corruption, resulting in a positive correlation between the two (Leite and Weidmann 2002). Gylfason finds a robust correlation between corruption and the abundance or intensity of natural resource exploitation, estimating that a $15 \%$ increase in the share of natural capital in national wealth is correlated with a 20 percentage point drop in the corruption perceptions index (2001). Vicente finds increases of up to $40 \%$ in corruption in vote buying, education, and customs in São Tomé and Principe following the announcement of an oil discovery (2009). ${ }^{5}$

3.4 Macroeconomic instability and export concentration. Dependence on natural resources seems to have negative implications for macroeconomic performance, especially by increasing vulnerability to external price shocks and reinforcing a narrow export base. One of the earliest models of how natural resources cause poor economic performance, dubbed "Dutch Disease" after an oil discovery in the Netherlands in the 1970s, posits that a booming sector will draw capital and labor out of all other tradable sectors (Corden 1984). Growth may be depressed more by this crowding-out effect of natural resources than by their negative effect on state bureaucracy (Sachs and Warner 1995). There may also be weaker political pressure on the

opportunities to finance civil wars with natural resource rents (Collier and Hoeffler 2000), scholars introduced a number of variants related to combatants' interests in continuing to "do well out of war" (Collier, Hoeffler, and Soderbom 2004), the increased incentives of state capture (Ross 2004b), or the increased incentives for external actors such as corporations or neighboring governments to interfere (Ross 2004b). The "grievance" supporters contend that natural resources themselves help to create real grievances through the extraction process (Gedicks 2001), commodity price volatility (Switzer 2001), or unaccountable governance (Humphreys 2005).

${ }^{5}$ Vicente takes advantage of a natural experiment to isolate the effects of the oil discovery on corruption in Sao Tome and Principe (STP). He uses a difference-in-differences model that compares household surveys from Cape Verde, a resource-poor but otherwise remarkably similar island country, and STP before and after the oil discovery was announced. Perhaps fortunately for São Tomeans, the discovery turned out to be much smaller than initially thought. 
state to invest efficiently and maintain an open trade policy in states that derive a large portion of their revenues from resource rents (Auty 2001). The boom-and-bust cycle caused by volatile primary commodity prices harms manufacturing in particular, a sector that has historically been critical to economic transformation (Sachs and Warner 1995; Karl 1997).

3.5 Poverty. Despite expectations that natural wealth should increase incomes, the curse suggests the opposite to be true: from 1960 to 1990, the economies of resource-poor countries grew two to three times faster than resource-rich countries (Auty 2001). Many of the negative outcomes explored in the previous paragraphs-macroeconomic volatility, corruption, conflict-may explain why natural resources ultimately lead to high rates poverty. Resourcerich countries may also fail to invest in development-particularly through education-because the demand for high-skilled labor is so minimal (Gylfason 2001). New research on the quality of institutions may provide further insights, arguing that rentier states have little incentive to invest in human capital (Mehlum, Moene, and Torvik 2006).

3.6 Social contract. Much of the disparate research on the resource curse can be interpreted as a break-down in the social contract between citizens and the state. Resource rents are "unearned income" that reduce the state's need for normal taxes, thereby diminishing its accountability to its citizens and making it dependent on a small group of oil companies. As rents increase, so do the incentives for civil servants and politicians to engage in patronage and rent-seeking, making them increasingly beholden to the resource sector rather than the citizenry (Karl 1997). At a macro level, these perverse incentives can be measured as a decrease in the rule of law, which tends to be much lower in resource-dependent countries. Subramanian and Sala-i-Martin find that the entire effect of resources on economic growth can be attributed to the depressing effect of resources on the rule of law (2003). Provision of public services also suffers: Gylfason found a strong negative relationship between natural resource dependence and secondary-school enrolment (2001). The tendency of rents to sever the state's accountability to its citizens is arguably resources' most pernicious long-term effect-and may be one significant explanatory channel for the other negative outcomes associated with oil and other natural resources.

In sum, natural resources and especially oil have come to be closely associated with a host of negative political and economic outcomes. In fact, many of the ways in which Ghana is considered to have been successful are the very same areas where oil is thought to have its most damaging effects. The policy concern is thus to create incentives to protect Ghana's progress and find ways of using future oil revenues to reinforce the virtuous cycle of the country's emerging social contract rather than allow oil to create a vicious cycle in the opposite direction. Indeed, this is the single most critical policy question facing Ghana.

\section{Schemes to Avoid the Curse}

Policy responses to counter the resource curse have met with vastly different results. One apparent factor that separates Norway from Nigeria seems to be how well policies shape the 
interests of actors who have access to resource rents. The academic literature on natural resources suggests that the breakdown in the social contract is one important channel for many of the negative effects. If correct, this implies that any policy solution must try to compensate for the interruption of the state-citizen accountability that has led to developmental dynamics in other countries. In countries that already suffer from rule of law and governance deficits, this has proven particularly difficult. Policy intervention to manage natural resource rents appears to have worked in countries where there is not only a mechanism for holding government actors accountable, but also a politically powerful group that has a strong interest in continued sound management. In other words, public policy seeking to sustainably avoid the natural resource curse should explicitly aim to create a constituency for responsible management of that resource wealth.

4.1 A Few Successful Examples: Botswana, Norway, and Alaska. Though the policies employed in Botswana, Norway, and Alaska are diverse at first glance, they are all similar in one regard: each approach fostered a constituency for responsible resource management and found mechanisms to hold government accountable. Norway and Botswana, partly by chance of history, happened to have highly influential constituencies with an interest in responsible management of oil and diamonds, respectively. Alaska creatively (but also with a bit of timely luck) manufactured such a constituency from scratch by instituting a system of direct distribution, which created a powerful incentive for all citizens to oversee the management of oil rents and for politicians not to dare encroach.

Botswana, the world's largest producer of gem-quality diamonds, appears to have escaped the resource curse. It is a stable, peaceful democracy and experienced the highest per-capita growth rate in the world between 1965 and 1998. The country has used its wealth to invest heavily in infrastructure and education; it is one of the only countries in Africa to provide universal access to treatment for HIV/AIDS. ${ }^{6}$ The secret of its success is neither entirely clear nor necessarily replicable, and many explanations tend to be circular: good economics has led to good politics, and vice-versa. However, one particular factor that stands out is pre-colonial institutions that enabled citizens to hold government accountable. Pre-colonial Tswana society enabled commoners to make recommendations and criticize chiefs, thus creating institutions that encouraged participation and limited the power of elites. British colonial rule was limited, so pre-colonial institutions persisted through independence. Furthermore, politically-influential cattle ranchers benefited from public spending of diamond revenues during the postindependence period, and political elites had little need for patronage spending due to the overwhelming dominance of the ruling party. When diamond rents came on-stream in the 1970s, powerful interests complied with existing institutions to avoid "rocking the boat" and disrupting the stream of wealth (Acemoglu, Johnson, and Robinson 2002).

When Norway discovered oil in the 1970s, democratic institutions had been in place for over 150 years in a society that was characterized by small political differences and egalitarian

\footnotetext{
${ }^{6}$ Diversification remains a shortcoming. Over the past ten years, diamonds contributed an average of $38.5 \%$ of GDP and $75 \%$ of total annual exports (Basdevant 2008).
} 
values. Therefore, policymakers responded to the demands of a broad coalition of non-oil exporters by implementing policy focused on maintaining the competitiveness of the non-oil sectors during the 1970s and 1980s. In 1990, upon rising concerns about the state's ability to pay for pensions for Norway's aging population, the government set up the State Petroleum Fund to save for future expenditure commitments (Eifert, Gelb, and Tallroth 2002). The Fund is required to invest its assets abroad to reduce the appreciation of the real exchange rate, but rules regarding inflows and outflows are flexible (Fasano 2000). In the presence of strong institutions based on consensus and transparency, Norway's policymakers have an interest in catering to a large, empowered constituency that demands pro-stabilization policies and savings over the long term.

In Alaska, the Permanent Fund was set up almost immediately after oil was discovered in the 1970 s as an investment base that would produce revenue even as future oil production decreased. The Fund's principal cannot be spent without amending the state's constitution by a majority vote of the population, and it must invest outside Alaska to help stabilize the state's income. One of the immediate stimuli for the Fund was the public belief that Alaskan politicians had wasted a $\$ 900$ million payment for exploration rights on unsustainable government programs. In 1982, the government instituted the Permanent Fund Dividend (PFD) program, a regular cash transfer of the Fund's interest earnings to state residents, to give Alaskans an individual interest in protecting the fund (Fasano 2000). In recent years households have been receiving about $6 \%$ of their income on average from the PFD, as about US $\$ 1$ billion per year is distributed among 600,000 citizens (Goldsmith 2002). The PFD is now a regularly anticipated component of household income, and most politicians consider it "political suicide to suggest any policy change that could possibly have any adverse impact today, or in the future, on the size of the PFD" (Goldsmith 2002). The dividend has been "extremely successful in creating a political constituency for the Permanent Fund that did not previously exist" (Goldsmith 2002).

Thus, despite innumerable differences between Botswana and Norway, both countries inherited conditions, prior to discovering their natural wealth, whereby the incentives of political actors were set by strong democratic institutions and empowered constituents with an interest in responsible resource management. In Alaska, such a constituency was artificially created through the Permanent Fund Dividend. Powerful constituencies rooted in non-oil tradeable sectors may have also played a role in the relatively good management of natural resources in Chile, Malaysia, and Indonesia (Gelb 2009).

4.2 Two Obvious Failures: Chad and Nigeria. Most efforts to leverage resource wealth for development in Nigeria and Chad over the past fifty years have failed. In contrast to Botswana, Norway, and Alaska, officials do not appear to have been constrained by either institutions or powerful constituencies. Instead, influential groups found it more fruitful to encourage and engage in rent-seeking rather than institutional limits on the actions of elites. The World Bank's attempt to insulate oil wealth from Chad's polity failed because there was nothing to prevent Chadian politicians from reneging on the arrangement. In Nigeria, a similar institutional vacuum has allowed government actors to squander its vast oil wealth. 
Chad is an interesting case. The country discovered oil in the mid-nineties, but required a pipeline through Cameroon in order to export. The World Bank and major international oil companies designed a highly public experiment that sought to extract oil wealth from a country facing severe governance deficits without unleashing the resource curse. The Bank conditioned financing for the pipeline on agreement by the Government of Chad to put all direct oil revenues into an offshore escrow account and agreeing to adhere to strict spending requirements: $80 \%$ would go for direct development and poverty reduction expenditures, $10 \%$ set-aside for a Future Generations Fund, $5 \%$ on the oil-producing region, and the remaining $5 \%$ for discretionary spending (Republic of Chad \& IBRD 2001).

The deal began to fail almost immediately after oil began pumping in October 2003. Much of the first tranche of revenues was spent on the military (World Bank 2007a). The civil society watchdog that was supposed to oversee development expenditures was created on paper but never funded. In 2005, Chad's parliament abolished legislation committing itself to the Future Generations Fund and increased the ceiling on discretionary spending (World Bank 2005). In 2008, after Chad paid back all the World Bank's loans, the Bank formally pulled out (World Bank 2008). The Bank was aware that its agreements with Chad would lose their teeth after the loans had been disbursed; it did not anticipate that Chad's legislators and president would face so little domestic opposition as they broke or abolished legislation that they had passed just a few years earlier. In hindsight, it seems that Chad's experiment may have failed due to the lack of institutions through which citizens could pressure politicians to manage oil revenues responsibly, no internal constituency for sticking to the deal, and no external player to enforce the agreement.

In Nigeria, oil revenues have flowed through public coffers like water through a sieve, as almost all attempts to control and utilize some of the massive natural wealth for development have been hijacked. Between 1970 and 1999, the Nigerian petroleum industry generated \$231 billion in rents, yet per capita income actually fell during this period (Ross 2003). As of 2004, almost two-thirds of Nigeria's population lives on less than $\$ 1.25$ per day (World Bank 2009). Branches of the Nigerian government have fought amongst themselves for control of the revenues-for example, between 1946 and 2003, the allocation formula to determine how much of oil revenues went to state and local governments changed 18 times-but the vast majority of Nigerian citizens have merely been spectators (Ross 2003; Ahmad and Singh 2003). Rather than becoming a constituency for sound oil management, many state governors have instead become actively complicit in the system of using public money for personal gain and political patronage. Outgoing administrations often looted the central bank with impunity. From independence in 1960 until 2003, there was not a single criminal conviction for corruption charges in Nigeria (Ribadu 2009). Perhaps this helps to explain why $70 \%$ of Nigerians report that they are not at all or not very satisfied with democracy (Lewis 2006). In this institutional environment, efforts to control spending through technical audits and compliance with due process have had only a marginal effect (Eifert, Gelb, and Tallroth 2002). 
A recent anomaly in Nigeria's experience is instructive. During the brief period of 2003-07, a dedicated and capable team of economists and technocrats attempted to change the way Nigeria was managed. Budget transparency was aggressively implemented, with income and expenditures published regularly and publicly, and the Due Process mechanism introduced competitive bidding for government contracts. A conservative oil price reference was used in the budget, and any revenues above this level were saved in a newly-created Excess Crude Account (ECA) at the central bank. The central bank itself was used to accumulate significant reserves, rising to nearly $\$ 30$ billion by 2005 , which enabled the country to buy back all of its outstanding external debts. In 2007 parliament attempted to consolidate these economic financial management measures by passing the Fiscal Responsibility Act, and the government encouraged states to pass similar legislation (Okonjo-Iweala 2008; International Monetary Fund 2008b). Nigeria was accepted as an Extractive Industries Transparency Initiative (EITI) candidate country in September 2007. Alas, this progress proved fragile. "Anti-reformers" whose opportunities for rent-seeking were cut off by the reforms fought back through spurious media campaigns and "false stories" told to top-level officials (Okonjo-Iweala and OsafoKwaako 2007). A change of administration in Nigeria has since seen reforms stall or regress party because of counter-attacks by these powerful constituencies.

In both Chad and Nigeria attempts to encourage more sound management ran into powerful constituencies with an interest to block or reverse their reforms. In Chad's case, there was little public reaction. In Nigeria, reform is on hold as of writing, but the final outcome appears perhaps less pessimistic given the unclear political direction of the country. The green shoots planted in 2003-07 may sprout again.

\section{A Proposal for Ghana: Direct Cash Distribution of Oil Receipts}

Where does this leave Ghana? The political and economic successes that Ghana has earned over the past twenty years are jeopardized by the impending oil revenues in 2011. Indeed, oil's insidious effects may already have begun to negatively affect Ghana's political economy. Public expectations of the benefits from oil wealth skyrocketed since 2007, in part because both major parties attempted to use it to their advantage during the 2008 campaigns (McCaskie 2008). Rising deficit spending, perhaps in part due to the anticipated influx of oil revenues, is already contributing to macroeconomic problems (International Monetary Fund 2008b). Rigorous implementation of proposed schemes to enhance the transparency of licensing, revenues, and spending are all good ideas and should help to encourage better use of Ghana's oil wealth.

We propose below a complementary policy option that will attempt to build the relationship between citizens and their state: direct distribution of the oil revenues to citizens. Sharing out oil funds directly to Ghanaians will provide them with an immediate highly-visible welfare benefit and, just as importantly, a direct incentive to actively participate in monitoring the revenue flow. At the same time, it will force the state to find ways of increasing taxation and the provision of public services. In fact, just such an approach can allow oil to strengthen, rather than destroy, Ghana's emerging social contract. 
5.1 Other (good) advice for GoG. There are many steps along the chain that transforms oil in the ground into development outcomes. A crude summary includes: licensing, production, receipts, budgeting, expenditure, and service delivery (Figure 7). At each of these steps are opportunities for value to be wasted and for public resources to be appropriated or stolen. Thus any basket of policies to make this chain work well-to turn oil into educated childrenshould address the breadth of the chain.

The Extractive Industries Transparency Initiative (EITI), of which Ghana is a candidate country, aims to shed light on the receipts portion by reporting incoming funds. Proposals for "EITI++" expand that transparency both backwards to the licensing and forward to the expenditure segments. The EITI framework will be helpful in Ghana's case, and some of the lessons learned from its experience in the mining sector can be applied to oil. However, while EITI can arm citizens with information about their government's finances it cannot by itself create the constituencies or mechanisms of accountability that appear to have been critical to avoiding the natural resource curse.

Figure 7: The Oil Production Chain and Interventions

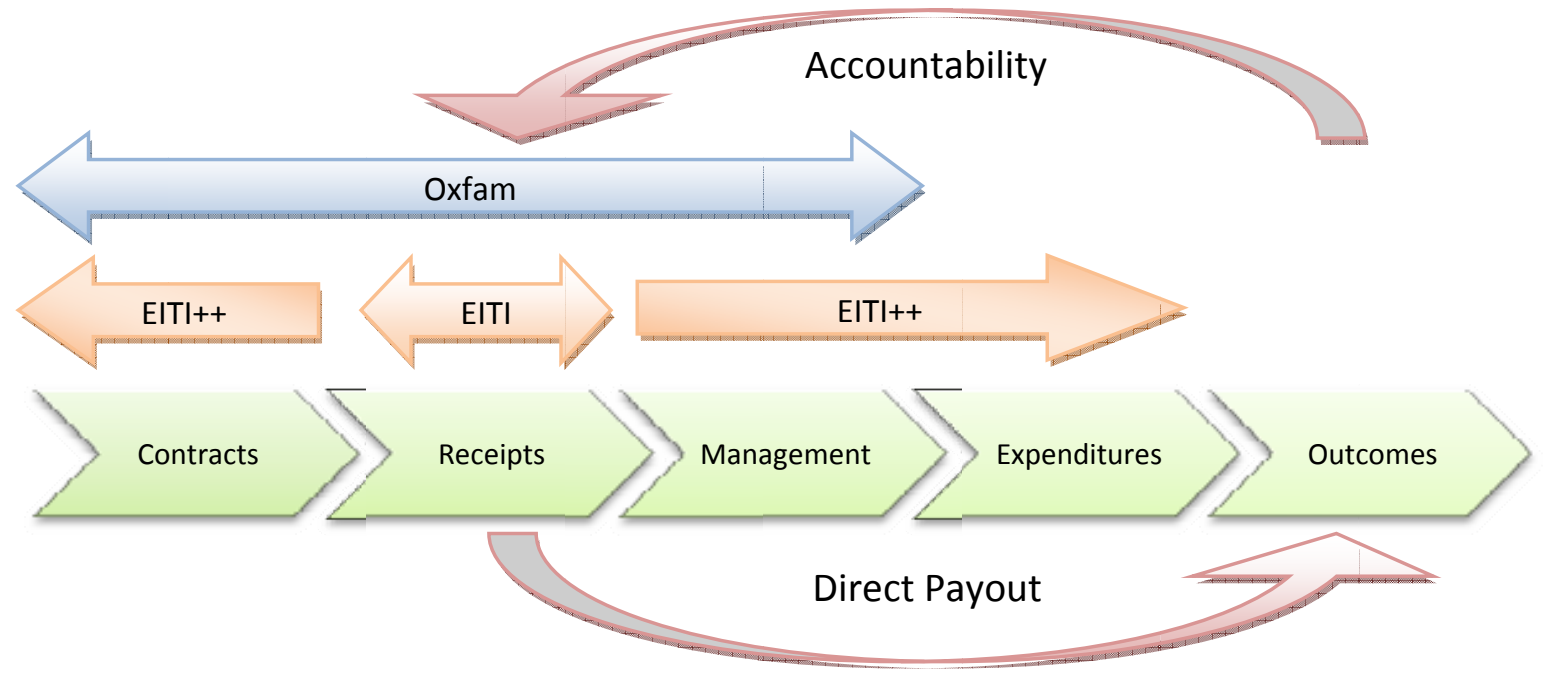

The government of Ghana has already begun to receive advice from outside NGOs and official agencies, particularly Oxfam, the IMF, and the Government of Norway, and to conduct national consultations on how to manage oil wealth. Oxfam published an exhaustive report proposing an impressive list of specific policy interventions that they deem necessary to preserve transparency, facilitate civil society oversight, and create an independent regulatory authority. ${ }^{7}$

${ }^{7}$ Oxfam leaves the question of what to do with the oil revenues largely unexplored, outside of warning against too much early spending. 
These proposals are smart and necessary, particularly the recommendation to resolve a serious conflict of interest by creating an independent regulatory body rather than letting the Ghana National Petroleum Corporation serve both commercial and regulatory functions (Gary 2009). If followed, the Oxfam recommendations will enhance the quality of public financial management and provide an opening for increased accountability to citizens.

The IMF and Norway are, separately, advocating the creation of an oil and gas revenue fund along the lines of the Norwegian model. Norway has signed a five-year memorandum with Ghana as part of its "Oil for Development" program and seems to have the ear of the government (Gary, Manteaw, and Armstrong 2009). The IMF appears most concerned with Ghana's fiscal deficit and potential inflation, and has recommended a "heritage fund" and investment in infrastructure (IMF 2009; Allen and Bougha-Hagbe 2008). Yet there are many reasons to doubt that a savings fund model from Norway would transfer directly to the Ghanaian context. First, Ghanaians face a significantly different problem than the one faced by Norwegian policymakers: poverty among a young and growing population, rather than protection of a welfare state with an aging populace. Moreover, a Norway-like fund model does not, by itself, provide for the political constituency to protect the fund. Such an approach would prove beneficial only if it changes the political incentives faced by policymakers (Humphreys and Sandbu 2007; Gelb 2008). In other words, even if a model ring-fenced account was created, what would prevent politicians from changing the rules? What would stop Ghana from essentially repeating the experience of Chad?

5.2 The case for direct cash distribution. We propose a complementary mechanism to fill the missing gap in the other set of proposals: direct cash distribution. Such an approach would allocate oil revenues in an equitable, transparent, and efficient way. Most importantly, distribution would reinforce good governance by creating incentives for both the state and citizenry to act prudently.

Such a radical step may be necessary in Ghana because policies that bind governments to periodic disclosures, spending floors or ceilings, or savings percentages are ultimately fragile without powerful domestic groups to hold the government accountable (Humphreys and Sandbu 2007). Increased transparency provides useful tools but not immediate incentives for citizen action. In Norway, Botswana, and Alaska, resource wealth was well-managed in part because institutions enabled groups interested in the sustainable management of oil wealth to influence policy. At the moment, Ghana does not have an interest group that will fill this monitoring and enforcement role.

Ghana can create just such a constituency by following a version of Alaska's model of direct distribution. In Alaska, the Permanent Fund Dividend is a regular transfer that citizens rely on as part of their income. As a result, it has become politically unthinkable to consider any change to the fund that would jeopardize the dividend. Ghana needs a similar system to give the entire 
population a sense of ownership over the fund's revenues. ${ }^{8}$ In this way, Ghana can manufacture, from scratch, the constituencies that demand responsible resource rent management-and become more like Norway, Botswana, and Alaska, and less like Chad and Nigeria.

Direct distribution also increases the state's dependence on its citizens. To get some of the revenues back, the state will have to tax them, and justify its taxes with public services. In fact, giving people more money will create additional incentives for the revenue authorities to improve tax collection. As we have suggested above-borrowing from Kaldor (1963), Tilly (1975), North and Weingast (1989), Ross (2004a), and Moss, Pettersson, and van de Walle (2008) - taxation is not just desirable, but essential to building a responsive state. Therefore, handing cash directly to citizens and forcing the tax authorities to find ways to tax some of it back is not a cost but rather a benefit of this scheme.

There are also strong equity considerations in the case of Ghana but, again, this would appear to support an argument for distributing the money equally rather than hoping for fixes in public policy biases. Public spending in Ghana has been strongly skewed towards the relatively wealthier south, so an equal payout to each citizen will inherently be more progressive than spending it through government systems (Canagarajah and Ye 2001). ${ }^{9}$

Last, and perhaps most importantly, payments have an immediate standard of living impact. This is no small benefit in a country where average income is still under $\$ 400$ per year and poverty is still prevalent. There is no better way to ensure that all Ghanaian citizens enjoy the benefits of the country's oil than to give them cash-in-hand. While it is impossible to predict the savings-consumption patterns likely in Ghana from an oil bonus, spending patterns in other countries including Kenya and Alaska suggest that individuals may save a higher proportion of revenues during commodity booms than the government (Bevan, Collier, and Gunning 1987, 1989, and 1992, Hsieh 2003).

More to the point, even if the oil payments did primarily go toward consumption, is that necessarily a bad outcome for a country in Ghana's circumstances? Indeed, one could argue that enhanced "consumption" for the majority of Ghanaians living near or below the poverty line would mean greater spending on food, housing, and other day-to-day expenses. Consumption that leads to improved nutrition and living standards might thus be better considered "investments" in human capital. ${ }^{10}$

\footnotetext{
${ }^{8}$ Sandbu (2006) cites three psychological forces that may account for the positive effects of direct distribution on governance: 1. Reference dependence: people pay more attention to changes in income levels than to the levels themselves. 2. Loss aversion: losses loom larger than gains. 3. Framing: reference points are susceptible to framing.

${ }^{9}$ Measured in terms of the student-teacher ratio, educational subsidies, public health facilities, public hospitals, or subsidies to non-public hospitals, the three northern regions (Northern, Upper West, and Upper East) receive a smaller share of public spending.

${ }^{10}$ Thanks to Charles Kenny for this insight.
} 
Combining all these advantages of our proposed approach, direct distribution of oil revenues would provide Ghana a way to explicitly leverage oil dollars to do the opposite of the resource curse: to strengthen, rather than destroy, the nation's emerging social contract. (Below we address some likely objections to direct cash distribution.)

5.3 How much money are we talking about? The IMF projects that the Ghanaian government's revenues from oil production will reach $\$ 1.3$ billion per year by 2013 , and remain at or slightly above that level until 2022. Actual revenue may be significantly higher, as the IMF based its estimations only on the initial evaluations of one of several fields. ${ }^{11}$ To put these numbers in perspective, $\$ 1.3$ billion is equivalent to nearly $40 \%$ of estimated total government revenue in 2009. In fact, gold and cocoa have been the mainstays of Ghana's economy for more than a century, but oil will soon surpass both of these commodities as a percentage of government revenue and exports (Figure 8). ${ }^{12}$

Figure 8: Ghana exports, 1992-2015
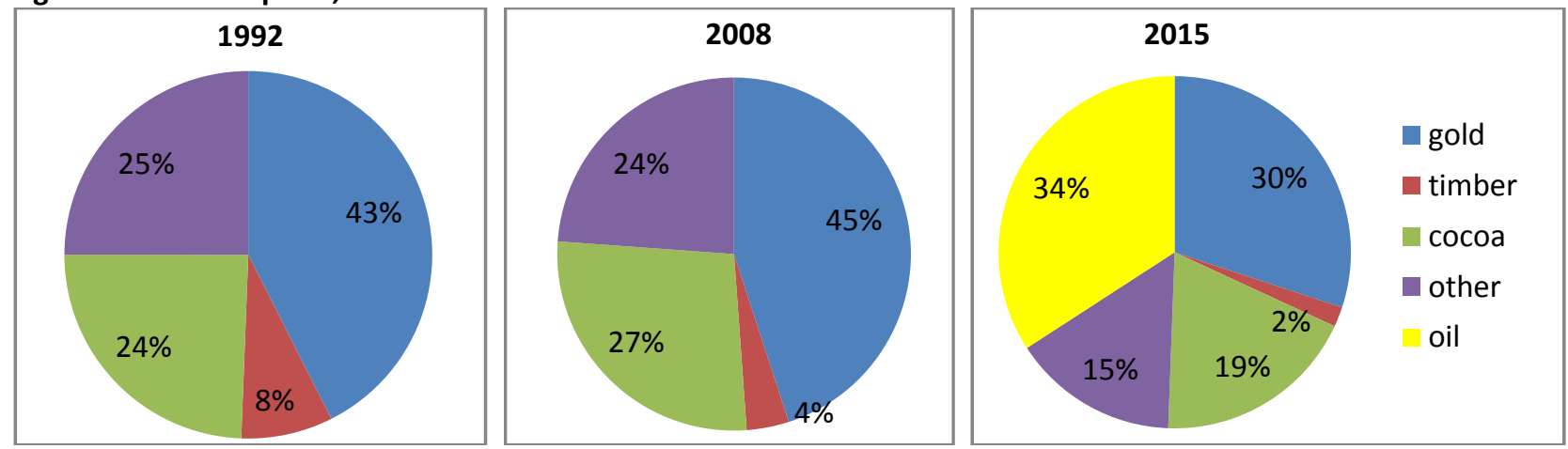

Based on these conservative projections, Ghana could thus give a hypothetical payout of more than US\$80 per adult, or US\$50 per person per annum, once oil production has scaled up to the expected steady level beginning in 2013 (Table 1). Considering that GDP per capita in Ghana is still less than US\$400 per year, a payout of even half this size would have a meaningful impact on the incomes of Ghanaian households. By comparison, the Alaska Permanent Fund Dividend is $6 \%$ of annual household income and still generates strong shared incentives to protect oil wealth. These payouts would grow substantially if there are additional oil discoveries, a rise in the oil price above the US\$60 per barrel assumption, or any favorable changes in contract terms.

\footnotetext{
${ }^{11}$ The IMF's revenue projections are based only on a production capacity of 120,000 barrels per day, which was the early evaluation of the Jubilee field's capacity. However, drilling in 2009 suggests that the field is larger than expected and of high quality (Petroleum Economist 2009). In addition, a number of other companies are exploring in adjacent fields .

${ }^{12}$ Ghana's exports are taken from the UN Comtrade SITC Rev. 3 database (United Nations Statistics Division 2009). Exports in 2015 are projected using the 1992-2008 compound annual growth rate for each commodity. Predictions of oil exports are taken from the IMF (International Monetary Fund 2008a).
} 
Table 1 Projections of Government Revenues from Oil Production

\begin{tabular}{|c|c|c|c|c|c|}
\hline & 2011 & 2012 & 2013 & 2014 & 2015 \\
\hline $\begin{array}{l}\text { Total government oil revenue } \\
{\text { (US } \$ \text { millions) }{ }^{13}}\end{array}$ & 752 & 723 & 1,324 & 1,326 & 1,352 \\
\hline \multicolumn{6}{|l|}{ Potential payout per person } \\
\hline $\begin{array}{l}\text { Projected population } \\
\text { (millions) }{ }^{14}\end{array}$ & 24.8 & 25.3 & 25.9 & 26.4 & 26.9 \\
\hline Payout / person (US\$) ${ }^{15}$ & 30.29 & 28.53 & 51.21 & 50.26 & 50.21 \\
\hline $\begin{array}{l}\text { Per person payout (\% of GDP } \\
\text { / capita) }{ }^{16}\end{array}$ & $9.0 \%$ & $8.2 \%$ & $14.1 \%$ & $13.3 \%$ & $12.8 \%$ \\
\hline \multicolumn{6}{|l|}{ Potential payout per adult } \\
\hline Adult population ${ }^{17}$ & 15.1 & 15.5 & 15.8 & 16.1 & 16.4 \\
\hline Payout / adult (US\$) 18 & 49.65 & 46.78 & 83.94 & 82.39 & 82.32 \\
\hline $\begin{array}{l}\text { Per adult payout (\% of GDP / } \\
\text { capita) }{ }^{19}\end{array}$ & $14.8 \%$ & $13.4 \%$ & $23.1 \%$ & $21.8 \%$ & $20.9 \%$ \\
\hline
\end{tabular}

To gain the maximum benefits from the scheme, Ghana would ideally distribute the majority of the country's oil revenues each year, minus some small and publicly disclosed administrative fee. This would engender citizens' sense of ownership of resource rents, allow them to spend according to their own priorities, and limit the "leakage" from public spending on other

\footnotetext{
${ }^{13}$ Oil production assumptions are based on the IMF's projections during the last Article IV negotiations in October 2008. The IMF's projections are similar to those of the Ghana National Petroleum Corporation, but with slightly more conservative assumptions. The IMF delays the GNPC's predicted start date by one year, and takes a $10 \%$ prudential discount off of the World Economic Outlook projected oil prices through 2014, after which they are assumed to remain constant (Ghana National Petroleum Corporation 2008; International Monetary Fund 2008a).

${ }^{14}$ Annual population projections are calculated using a compound annual growth rate based on the United Nations Department of Economic and Social Affairs, which are published for every fifth year (2008).

${ }^{15}$ Payout per person is calculated by the author based on the IMF's oil revenue projections and UNESA population projections.

${ }^{16}$ GDP per capita is projected based on real 2005 GDP per capita (World Bank 2007b) and a high estimated GDP per capita annual growth rate of $4 \%$ (which makes our estimates of the payout as a percent of GDP per capita more conservative). Per capita payout as a percent of GPD/capita is calculated by the author using the projected oil revenues and GDP/capita.

${ }^{17}$ Adult population is calculated based on a projected percentage of adults (ages 15 and over) that remains stable at $61 \%$ (2005 statistic) of Ghana's population until 2015 (World Bank 2007b).

${ }^{18}$ Payout per adult follows the same population and revenue projection assumptions as payout per capita and adult population.

${ }^{19}$ Per adult payout as a percent of GPD/capita is calculated by the author using the projected oil revenues, adult population, and GDP/capita.
} 
projects. Alternatively, the government could set some fiscal rules to either (a) mitigate yearon-year volatility or (b) to save funds for other purposes.

a) Given the volatility of oil prices, year-on-year payments could fluctuate tremendously. To limit this effect, the government could make payments based on 2- or 3-year rolling averages or simply cap payments as a percentage of GDP per capita. This could smooth payments and create a savings pool.

b) The government could, of course, decide to allocate only a portion of the revenues for direct distribution, say $50 \%$ or $75 \%$, and allocate the remainder for other purposes as deemed desirable, such as a future generations fund, an infrastructure fund, or a conditional cash-transfer education fund. Optimally, these allocation ratios would be enshrined in the constitution to limit ex post changes (see below).

Timing also works in Ghana's favor for several reasons. The lead time until revenues flow-nearly two years as of this writing-remain sufficient to put in place a mechanism before entrenched interests grab hold of oil revenues. The country will also conduct the next census in 2010, so population data will be as accurate as it could ever be when oil revenues start accruing in 2011. Perhaps most importantly at the current time, President John Atta Mills is a former tax professor and head of the Internal Revenue Service. His administration, perhaps more than any other administration on the continent, grasps the importance and mechanics of revenue collection. Indeed, if Ghana ever wants to build a social contract as a defense against wasteful spending, this is exactly the moment.

5.4 Principal objections to direct distribution. ${ }^{20}$ A common protest to direct distribution is that it would deny the government resources to provide much-needed public services and investments in infrastructure. Yet this objection ignores evidence that resource rents pervert government incentives such that they too frequently fail to invest in human development. Despite Ghana's admirable track record, the experiences of other resource-rich countries suggests that rents spent through government systems would leak into the pockets or patronage networks of politicians-unless there is some mechanism to preserve the government's accountability.

Neither would direct distribution subvert public policy, as the government would in practice tax back a healthy percentage of the distribution. In this sense, Ghana seems ideally placed to take advantage of this opportunity for several reasons. It already collects a healthy $20-25 \%$ of GDP in taxes per year, suggesting existing collection capacity (World Bank 2009). Ghana has also embarked on tax reform, such as the 1998 implementation of a value-added tax, which at 15\% would itself recover a significant percentage of the funds spent on consumption. Higher incomes among the general population create additional opportunities for the authorities to consolidate tax reforms and broaden the tax base. ${ }^{21}$

\footnotetext{
${ }^{20}$ We borrow liberally from Birdsall and Subramanian (2004) in this section.

${ }^{21}$ Another possible objection to this proposal is the inflation risk. However, there is little reason to believe that direct consumer activity would be more inflationary than government spending.
} 
Critics could contend that getting political consensus to move to direct distribution is nearly impossible since politicians have no incentive to give up access to oil wealth. Yet the politics of getting there may actually be quite simple. Once the proposal is publicly floated in Ghana and begins to get some vocal support, resistance may become politically dangerous, as happened in Alaska. Ghanaian politicians will recognize that promoting a proposal to put cash in the hands of their constituents will become quickly and deeply popular. Ideally, the provision for oil management would become enshrined in the constitution, either through a two-thirds vote in parliament or a $75 \%$ "yes" vote by referendum. ${ }^{22}$ The threat of a referendum might in fact make it unnecessary.

5.5 The distribution mechanism. A more practical source of concern is the fear that Ghana does not have the capacity to distribute a direct payout. Certainly, the mechanism would itself require careful consideration. The legitimacy of the scheme rests on the ability to credibly reach all citizens and the confidence that fraud could be contained. However, it should be logistically easier for the government to give out a cash payment than to implement complex development projects. As Birdsall and Subramanian (2004) point out, it is reasonable to assume that it would be easier to give out a payout for many reasons - not least of which because citizens would naturally be quick to cooperate. In addition, the infrastructure needed to distribute payouts can be subsidized by resource rents, and will likely have positive spillovers.

There are multiple possible mechanisms for such a scheme, which will require two interlinked but distinct capabilities: personal identification and the transfer of cash. There are several potentially workable systems. The formal banking sector and network of post offices are both potentially viable, but technological leapfrogging may offer Ghana other more convenient options. Biometric ID cards and the mobile phone network seem particularly promising. The Bank of Ghana has been rolling out a system of biometric IDs for the past year, but an influx of funds dedicated to facilitating direct payouts could help the system scale up, thus laying the groundwork for more efficient voting, banking, and other services. ${ }^{23}$

In terms of getting the money out, the telecommunications network is unmatched in terms of reach and efficiency. Recent statistics suggest nearly 12 million active mobile phone subscriptions out of a population of about 24 million, but perhaps more importantly, the vendor networks that sell prepaid airtime cards are available in every rural outpost (National Communications Authority 2009). Mobile firms in Kenya have successfully launched a money transfer system called M-PESA through special cell phone SIM cards; a similar system has just launched in Ghana that would enable citizens to have their payouts transferred directly to their mobile phones or to a local airtime vendor. Competition between companies could be used to

\footnotetext{
${ }^{22}$ According to the Ghanaian constitution, a new amendment can be passed by a 2/3 vote of the Parliament (amending an "entrenched provision," on the other hand, requires a referendum in which $40 \%$ of the population votes and $75 \%$ of voters are in favor).

${ }^{23}$ The card system, "e-zwich", can also be used as a cashless payment system, but at this point the specialized infrastructure needed to process payments or withdraw cash is severely lacking. See www.e-zwich.com.
} 
drive down costs, while consumer protection systems are already available to prevent loss, theft, or identity fraud that will transfer easily to protecting streams of cash payouts. Some initial start-up costs or handset subsidies may be necessary, but these could come out of the initial payments. ${ }^{24}$ In addition to money transfer, spreading the mobile phone network would have other ancillary benefits. ${ }^{25}$

While the potential options and combinations are multiple, these technologies are rapidly changing. The most practical approach for Ghanaian policymakers may be to decide these choices through an open competitive bidding process. An open bid that laid out the purposes and then judged proposals based on cost, accessibility/universal coverage, fraud protection, and both positive and negative externalities would likely result in a mechanism very different (and almost certainly better) from those designed ex ante by policymakers (or foreign thinktank economists).

\section{Conclusion}

The trajectory of Ghana over the next fifty years will be largely set by the decisions taken by the government in the next 12-18 months. We have suggested that, based on the experiences of a wide range of countries, the country faces a significant threat if it makes the wrong choices or does not act boldly enough. We have argued that Ghana can save itself from its oil by putting the cash directly into the hands of its own people. The proposal for direct cash distribution laid out here is certainly a risky proposition. Policymakers tend to be wary of putting too much control of resources into the hands of ordinary people. Surely officials in Accra, and their counterparts in the capitals of Ghana's major creditors, can conceive of ways to spend the country's oil revenues on well-meaning development projects. And elaborate schemes can also be constructed to enhance oversight, limit the amount of funds lost, and to mitigate some of the effects of the oil curse. But our review of successful natural resource revenue management suggests that without the domestic political constituency to demand and sustainably enforce such measures, they are unlikely to succeed over the long term. Thus the modest options facing Ghana are in fact the riskier ones.

\footnotetext{
${ }^{24}$ Certainly low-cost handsets bought in bulk would be much less than the first annual payment, plus part of the subsidy could be spread over several years through the administrative cost paid to the service provider.

25 There are large positive externalities associated with going through the telecom networks, in addition to cost savings. Cell phones can help markets work more efficiently (Aker 2008), be used to help strengthen health systems and delivery (Kalil 2008), and even engage citizens and protect civil rights (Schuler 2009). If the distribution mechanism gives people an incentive to plug into mobile banking systems, another set of potential benefits are introduced. Savings and access to credit helps the poor smooth their income, insure against risk, and broaden their investment opportunities (Claessens 2006).
} 


\section{Annex 1: Formula for Government Share of Oil Revenues (Ghana National Petroleum Corporation 2008)}

"The benefits from any discovery are spelt out in the Petroleum Agreement before its execution. In the case of Kosmos/Tullow discoveries the State derives its benefits from Royalty of $5 \%$, Carried Interest of $10 \%$, Average Additional Interest of $3.75 \%$ and Income Tax of $35 \%$.

"Let us assume a production of 100,000 barrels per day, which is the minimum expected from the Mahogany/Hyedua Field in full field development. The computation of the State's benefits is shown in the Table below:

Fiscal Benefits to the State (Assuming 100,000 Barrels per day @ US $\$ 60$ per Barrel
Reserves of $\mathbf{5 0 0}$ million barrels and Production

Period of Fifteen (15) Years

"From the above computation, oil accruing to the State would be calculated as 38,209 barrels per day out of 100,000 barrels per day production and this multiplied by an assumed long term price of US $\$ 60$ a barrel amounts to US $\$ 2,292,540.00$ per day which would translate to US $\$ 836,777,100.00$ per annum.

"A daily production of 200,000 barrels which could be achieved 5 years after commencement of production could give the State a total revenue of approximately US\$1.6 billion per annum." (Ghana National Petroleum Corporation 2008) 
Acemoglu, Daron, Johnson, Simon, and Robinson, James A. 2002. "An African Success Story: Botswana." CEPR Discussion Paper No. 3219.

Ahmad, Ehtisham, and Singh, Raju. 2003. "Political Economy of Oil-Revenue Sharing in a Developing Country: Illustrations from Nigeria." IMF Working Paper.

Aker, Jenny. 2008. "Does Digital Divide or Provide? The Impact of Cell Phones on Grain Markets in Niger." Center for Global Development Working Paper 154.

Allen, Richard, and Bougha-Hagbe, Jacques. 2008. "Ghana Aims for Firmer Fiscal Discipline before Oil Flows." IMF Survey Magazine: Countries and Regions.

Aryeetey, Ernest, Harrigan, Jane, and Nissanke, Machiko. 2000. Economic Reforms in Ghana: The Mirage and the Miracle. Trenton, New Jersey: Africa World Press.

Aryeetey, Ernest, and McKay, Andrew. 2007. "Ghana: The Challenge of Translating Sustained Growth into Poverty Reduction." In Delivering on the Promise of Pro-Poor Growth: Insights and Lessons from Country Experiences, eds T Belsey and L Cord. New York: Palgrave Macmillan.

Asamoa, Yaw Buaben. "National Strategies for Combating Corruption; The Ghana Experience." Addis Ababa.

Auty, Richard. 2001. "The Political Economy of Resource-Driven Growth." European Economic Review.

Basdevant, Olivier. 2008. "Are Diamonds Forever? Using the Permanent Income Hypothesis to Analyze Botswana's Reliance on Diamond Revenue." IMF Working Paper.

Bevan, David, Collier, Paul, and Gunning, Jan Willem. 1987. "Consequences of a commodity boom in a controlled economy: Accumulation and redistribution in Kenya 1975-1983." World Bank Economic Review 1(3).

Bevan, David, Collier, Paul, and Gunning, Jan Willem. 1989. "Fiscal response to a temporary trade shock: The Kenyan coffee boom." World Bank Economic Review 3(3).

Bevan, David, Collier, Paul, and Gunning, Jan Willem. 1992. "Anatomy of a temporary trade shock: The Keynan coffee boom of 1976-9." Journal of African Economies 1(2).

Birdsall, Nancy, and Subramanian, Arvind. 2004. "Saving Iraq from Its Oil." Foreign Affairs 83 (4): 77-89.

Bratton, Michael and Cho, Wonbin. "Where Is Africa Going? Views from Below." Capetown.

Canagarajah, Sudharshan, and Ye, Xiao. 2001. "Public Health Spending in Ghana in 1992-98: Issues of Equity and Efficiency." World Bank Policy Research Working Paper No. 2579. Washington, DC.

Carothers, Thomas. 2002. "The End of the Transition Paradigm." Journal of Democracy.

Carter Center. 11-6-1992. "Report of the Carter Center Ghana Election Mission." http://www.cartercenter.org/documents/electionreports/democracy/FinalReportGhana 1992.pdf.

Carter Center. 12-9-2008. "Ghana's Voters Renew Commitment to Open and Competitive Elections." http://www.cartercenter.org/news/pr/ghana elections prelim statement 2008.html.

Centre for Good Governance and Institute for Policy Alternatives. "Election Violence Monitoring of the Presidential and Parliamentary Elections, Ghana, 2004." Accra. 
Claessens, Stijn. 2006. "Access to Financial Services: A Review of the Issues and Public Policy Objectives." The World Bank Research Observer 21 (2).

Collier, Paul, and Hoeffler, Anke. 2000. "Greed and Grievance in Civil War." World Bank Policy Research Working Paper No. 2355.

Collier, Paul, Hoeffler, Anke, and Soderbom, Mans. 2004. "On the Duration of Civil War." Journal of Peace Research.

Corden, W. M. 1984. "Booming Sector and Dutch Disease Economics: Survey and Consolidation." Oxford Economic Papers 36 (3): 359-380.

Diamond, Larry. 2008. The Spirit of Democracy. New York: Macmillan.

Eifert, Benn, Gelb, Alan, and Tallroth, Nils. "The Political Economy of Fiscal Policy and Economic Management in Oil Exporting Countries." Washington, D.C.

Fasano, Ugo. "Review of the Experience with Oil Stabilization and Savings Funds in Selected Countries." Washington DC.

Gary, lan. "Ghana's big test: Oil's challenge to democratic development."

Gary, Ian, Manteaw, Steve, and Armstrong, Clive. 2009. "Ghana's Big Test: Oil's Challenge to Democratic Development." Washington, DC: CSIS.

Gedicks, Al. 2001. Resource Rebels. Cambridge: South End Press.

Gelb, Alan, and Grasmann, Sina. 2009. “Oil Rents: How to Use Them Well?” Paper presented at the GDN Conference, Kuwait, February 2009.

Gelb, Alan, and Grasmann, Sina. 2008. "Confronting the Oil Curse." Paper presented at the $6^{\text {th }}$ annual Afd/EUDN conference in Paris, France, November 2008.

Gelb, Alan. 1988. Oil Windfalls: Blessing or Curse? Oxford: Oxford University Press.

Ghana National Petroleum Corporation. "The Upstream Petroleum Industry in Ghana." Accra, Ghana.

Goldsmith, Scott. "The Alaska Permanent Fund Dividend: An Experiment in Wealth Distribution." Geneva.

Gyimah-Boadi, E. "New Anti-Corruption Governments: The Challenge of Delivery: Ghana, A Case Study." Nairobi.

Gylfason, Thorvaldur. 2001. "Natural Resources and Economic Growth: What Is the Connection?" CESifo Working Paper No. 530.

Humphreys, Macartan, and Sandbu, Martin. 2007. "The Political Economy of Resource Funds." In Escaping the Resouce Curse, eds M Humphreys, J Sachs, and J Stiglitz. New York: Columbia University Press.

Humphreys, Macartan. 2005. "Natural Resources, Conflict, and Conflict Resolution: Uncovering the Mechanisms." Journal of Conflict Resolution.

International Finance Corporation. 2009. "Doing Business: Measuring business regulations." http://www.doingbusiness.org/.

International Monetary Fund. "Ghana: 2009 Artice IV Consultation.” Washington, DC. International Monetary Fund. "Ghana: 2008 Article IV Consultation." Washington, DC. International Monetary Fund. "Nigeria: 2007 Article IV Consultation." Washington, DC. Jeffries, Richard. 1998. "The Ghanaian Elections of 1996: Towards the Consolidation of Democracy?" African Affairs 97 (387): 189-208.

Jeffries, Richard, and Thomas, Clare. 1993. "The Ghanaian Elections of 1992." African Affairs 92 (368): 331-366. 
Kaldor, Nicholas. 1963. "Will Underdeveloped Countries Learn to Tax?" Foreign Affairs. Kalil, Thomas. "Harnessing the Mobile Revolution."

Karl, Terry L. 1997. The Paradox of Plenty: Oil Booms and Petro-states. Berkeley: University of California Press.

Kaufmann, Daniel, Kraay, Aart, and Massimo, Mastruzzi. 2009. "Governance Matters VII: Aggregate and Individual Governance Indicators, 1996-2008." World Bank Policy Research Paper No. 4978.

Leite, Carlos, and Weidmann, Jens. 2002. "Does Mother Nature Corrupt? Natural Resources, Corruption, and Economic Growth." In Governance, corruption, and economic performance, eds G Abed and S Gupta. Washington, DC: International Monetary Fund.

Lewis, Peter. 2006. "Performance and Legitimacy in Nigeria's New Democracy." Afrobarometer. McCaskie, Tom. 2008. "The United States, Ghana and Oil: Global and Local Perspectives." African Affairs.

Mehlum, Halvor, Moene, Karl, and Torvik, Ragnar. 2006. "Institutions and the Resource Curse." Economic Journal.

Moore, Barrington. 1966. Social Origins of Dictatorship and Democracy: Lord and Peasant in the Making of the Modern World. Boston: Beacon Press.

Moss, Todd, Pettersson, Gunilla, and van de Walle, Nicolas. 2008. "An Aid-Institutions Paradox? Aid dependency and state building in Sub-Saharan Africa." In Reinventing Aid, ed W Easterly. Cambridge, MA: MIT Press.

National Communications Authority. 2009. "NCA: mobile penetration topped $98 \%$ in January." TeleGeography.

North, Douglass C., and Weingast, Barry R. 1989. "Constitutions and Commitment: The Evolution of Institutions Governing Public Choice in Seventeenth-Century England." Journal of Economic History 49 (4): 803-832.

Okonjo-Iweala, Ngozi. 2008. "Point of View: Nigeria's Shot at Redemption." IMF Economic Review.

Okonjo-Iweala, Ngozi and Osafo-Kwaako, Philip. "Nigeria's Economic Reforms: Progress and Challenges." Washington, DC.

Petroleum Economist. 2009. "Ghana: 'World-class' Jubilee oilfield larger than expected." Petroleum Economist.

Population Division of the Department of Economic and Social Affairs of the United Nations Secretariat. 2008. "World Population Prospects: The 2008 Revision." http://esa.un.org/unpp/p2k0data.asp.

Republic of Chad \& IBRD. 3-29-2001. "Loan Agreement (Petroleum Development and Pipeline Project)."

http://siteresources.worldbank.org/INTCHADCAMPIPE/Resources/td la en.pdf.

Ribadu, Nuhu. 2009. "Capital Loss and Corruption: The Example of Nigeria." U.S. House Committee on Financial Services.

Ross, Michael. 2001. "Does Oil Hinder Democracy?" World Politics 53 (3): 325-361.

----. 2003. "Nigeria's Oil Sector and the Poor." In Nigeria: Drivers of Change. London: DFID.

-----. 2004a. "Does Taxation Lead to Representation?" British Journal of Political Science 34.

-----. 2004b. "How Do Natural Resources Influence Civil War? Evidence from Thirteen Cases." International Organization. 
Sachs, Jeffrey, and Warner, Andrew M. 1995. "Natural Resource Abundance and Economic Growth." NBER Working Paper No. W5398.

Schuler, Ian. 2009. "National Democratic Institute: SMS as a Tool in Election Observation." Innovations 3 (2): 143-158.

Subramanian, Arvind, and Sala-i-Martin, Xavier. 2003. "Addressing the Natural Resource Curse: An Illustration from Nigeria." NBER Working Paper Series (9804).

Switzer, Jason. 7-11-2001. "Armed Conflict and Natural Resources: The Case of the Mining Sector." http://www.iisd.org/pdf/2002/envsec mining conflict.pdf.

Tilly, Charles. 1975. The Formation of National States in Western Europe. Princeton, NJ: Princeton University Press.

Transparency International. "Report on the Transparency International Global Corruption Barometer 2007." Berlin.

UNCTAD. 2009. "Foreign Direct Investment database." http://www.unctad.org/.

UNDP. 2007. "Ghana Human Development Report 2007." http://www.undpgha.org/docs/Human\%20Development\%20Report.pdf.

United Nations Statistics Division. 2009. "Comtrade Database." http://comtrade.un.org.

Vicente, Pedro. 2009. "Does oil corrupt? Evidence from a natural experiment in West Africa." Journal of Development Economics.

World Bank. 12-29-2005. "World Bank Statement on Changes to Chad Petroleum Law." http://go.worldbank.org/IHPOP4YGKO.

World Bank. 2007a. "Multi-Donor Mission Visited CHad from June 12 to 23, 2007." http://go.worldbank.org/T3ST3WTGVO.

World Bank. 2007b. "World Development Indicators." http://go.worldbank.org/SI5SSGAVZO.

World Bank. 9-8-2008. "World Bank Statement on Chad-Cameroon Pipeline." http://go.worldbank.org/LNOXOH2W50.

World Bank. 2009. "World Development Indicators." http://go.worldbank.org/3SGLDH5V10. 